\title{
An Investigation Into the Implementation and Selection of Literary Texts to Teach Reading Skills in EFL Classes: The Case of Preparatory Schools in Awi Zone, Ethiopia
}

\author{
Netsanet Haymanot Belete \\ Injibara University, Ethiopia \\ Sualih Mussa \\ Debre Markos University, Ethiopia
}

\begin{abstract}
This study was conducted to investigate the selection and implementation of literary texts for teaching of reading skills in English as a foreign language classes in preparatory schools in Ethiopia. In doing so, descriptive survey design was employed. To collect data, observation, questionnaire, interview and text analysis were used as data collection tools. Using simple random sampling technique, 30 grade 11 English teachers for questionnaire and 6 teachers for observation and interview were selected. Text analysis was also used to evaluate the suitability of literary texts. The study revealed that literary texts designed in grade 11 English textbook are not suitable for the students' age, interest, cultural background, social background, linguistic proficiency and literacy background. The reading tasks have almost no pre-reading activities, some while-reading activities and plenty of post-reading activities which are not well designed. Besides, EFL teachers perceived that literary texts are important to facilitate the students' reading classes but they were limited in using literary texts meaningfully. The study also revealed that difficulty level of literary texts, unfamiliarity of the cultures from texts, lack of interest, lack of reading experience and students' limited vocabulary were the major difficulties that hindered the proper use of literary texts in reading lessons.
\end{abstract}

Index Terms — literary texts, reading skills, selection, suitability, implementation

\section{BACKGROUND}

\section{A. Introduction}

Teaching English as a foreign language (TEFL) in Ethiopia is a challenging task which has many constraints. For many years, Ethiopia has followed the traditional approaches of teaching English language. As a result, English as foreign language (EFL) teachers were unable to achieve the goals of teaching English language. According to Freeman (1986), traditional approaches of teaching English language discourage the active involvements of students.

From the 1840s to 1940s, English language teaching was chiefly dominated by grammar translation method (GTM). Stern (1983: 454) states "Grammar translation lays little or no emphasis on the speaking and listening to second language."

Due to the above drawbacks, GTM has been highly criticized since it focuses on deductive ways of presenting grammar rules for the students. Later on, communicative language teaching (CLT) was introduced in 1950s. Freeman (1986) notes that in a communicative language classes, students are actively engaged in negotiating meaning in trying to make themselves understood even when their knowledge of the target language is incomplete.

To make the language teaching conducive, EFL teachers should use varieties of communicative techniques. Among the techniques, teaching language through literature is one way of improving students' language skills. As Lazar claims "Literature enriches the language input in classroom and stimulates acquisition by providing meaningful and memorable contexts for processing and interpreting new language (1993: 17)." The use of literature as a technique for teaching language skills is very popular within the field of foreign language learning and teaching.

Among the genres of literature, literary texts are appropriate to teach reading skills. Through literary texts, students can read, understand and enjoy the literary texts. Abdollah (2012) describes that literary texts are meaningful, authentic and relevant to learners' lives. Literary texts are rich in metaphor, simile and allusion, and these are the elements which deepen students' understanding of the literary texts. Therefore, students are inspired in reading literary texts to learn language in real life situations.

To use literary texts effectively, appropriate selection and implementation should be considered. Abdollah (2012) also adds that the selection of literary texts in relation to the needs, expectations, interests and language level of the students become significant. Thus, teachers need to focus on choosing appropriate literary texts and implementing 
appropriately.

\section{B. Statement of the Problem}

Although literary texts are valuable for students' language learning, they have been given less emphasis. Based on the researchers' experience, EFL teachers and students have given less attention for the literary texts; they also sometimes skip literary texts and focus on grammar contents.

Furthermore, different indigenous researchers have conducted studies on the same issue. For instance, Hanna (2016) conducted a study on the role of short stories in developing reading comprehension skill at Minilik II Preparatory School. Yenealem (2014) conducted a study on assessing teachers' and students' views regarding the role of literary texts in enhancing students' language use at Mena Secondary School. In addition, Alene (2012) conducted a study on teachers' and students' views towards using literary texts in reference to grade 12 at Aboker Preparatory School. By considering the gaps of the above studies, this study was made unique in its scope and variables. For instance, those studies did not focus on grade 11 EFL teachers, and none of them focused on the selection and implementation of literary texts to teach reading skills.

\section{Objectives of the Study}

This study mainly aimed to investigate the selection and implementation of literary texts to teach reading skills in EFL classes. Specifically, the study had the following specific objectives:

- To examine the appropriateness of literary texts to teach reading skills

- To determine the perception of EFL teachers towards the use of literary texts.

- To assess grade 11 EFL teachers' use of literary texts to teach reading skills in EFL classes.

- To identify the challenges of implementing literary texts to teach reading skills.

\section{Research Questions}

From the above specific objectives, the following questions were formulated.

- How appropriate are the selected literary texts to teach reading skills for grade 11 students?

- What is the perception of EFL teachers towards the use of literary texts?

- How do EFL teachers use literary texts to teach reading skills in EFL classes?

- What are the challenges of implementing literary texts to teach reading skills?

\section{METHODOLOGY}

\section{A. Design of the Study}

The researchers employed a descriptive survey research design that included both quantitative and qualitative data collection and analysis techniques. For this study, qualitative method of data collection and analysis was more important to describe the nature of the problem thematically. Hence, quantitative data was used to support the qualitative data since embedded design of mixed method of research was employed in this study.

\section{B. Sampling and Sampling Techniques}

The populations of this study were grade 11 EFL teachers at preparatory schools in Awi Zone. There were 61 grade 11 EFL teachers in all preparatory schools of Awi Zone. Among all EFL teachers, 30 grade 11 EFL teachers were selected for questionnaire from different preparatory schools by using simple random sampling technique. Similarly, 6 grade 11 EFL teachers for observation were selected by using simple random sampling. Moreover, the researchers also included these 6 observed EFL teachers for interview by using purposive sampling. This means, these EFL teachers who were observed were also interviewed to triangulate the data.

\section{Data Gathering Instruments}

So as to conduct this study, classroom observation, questionnaire, interview and textbook analysis were employed.

\section{Classroom Observation}

The classroom observation was conducted to check whether EFL teachers implemented literary texts to teach reading skills in EFL classes while the actual instruction was going on. For the purpose of classroom observation, qualitative observation checklist was employed.

\section{Questionnaire}

The purpose of administering questionnaire for EFL teachers was to examine the perceptions of EFL teachers towards the use of literary texts in EFL classes. The researchers adapted the questionnaire from Hana's (2016) study. The researchers prepared 30 close ended and 3 open ended items for sample grade 11 EFL teachers.

\section{Interview}

The purpose of this interview was to examine grade 11 EFL teachers' practices and challenges of using literary texts in reading lessons. In this study, semi-structured interview was conducted for selected EFL teachers.

\section{Textbook Analysis}

Textbook analysis was used to check whether grade 11 English textbook included suitable literary texts to teach 
reading skills. This tool was also used to evaluate the selection of literary texts designed to teach reading skills. They were evaluated based on the students' linguistic background, cultural background, background knowledge, age, interest, literacy background and linguistic proficiency.

\section{Validity and Reliability of Instruments}

To ensure the validity of the instruments, data collection tools were given to different people to check whether they were valid or not. Two experienced MA teachers were invited to examine the instruments. Consequently, some items of these tools were modified and others were omitted according to the suggestions and comments provided by these scholars. The researchers used pilot testing to check the reliability of the questionnaire. Then, they checked the overall reliability of the scale by using Chronbach alpha coefficient by using statistical package for social science (SPSS) version-20 and the result was 0.82 . This result demonstrates that the instrument has good reliability.

\section{DATA ANALYSIS}

\section{A. Analysis of EFL Teachers' Classroom Observation}

The first focus of observation sessions was to see whether EFL teachers focused on the linguistic features of literary texts while teaching reading through literary texts. As the researcher observed lessons of reading through literary texts, four EFL teachers were not focusing on linguistic features of literary texts. These teachers did not give attention to linguistic elements of literary texts while two EFL teachers defined vocabularies which were found in the literary texts. For instance, T3 defined some key words in the poem (Acoli cooking) on page 162. These words were "millet, dug, sweating, gourd, mounds, and gravy". Then, he defined these words to make the poem clear for the students.

Similarly, T5 in the story (The tale of a tap) on page 198 wrote key words (light heart, foggy head, tossed, gurgle and humanity) on the blackboard and gave equivalent meaning for these words. These EFL teachers only used some new words from the literary texts to define them for the students instead of focusing on other linguistic features of the language. However, the remaining four EFL teachers did not focus on the grammar use, pronunciation and style of language in the literary texts. For instance, T6 focused on the content knowledge of literature and plot structure. He explained,

There are basic elements of fiction in a given story. These are setting, plot, story, character, conflict and point of view. The setting is the place and time of a story, and the plot is the structure of conflict based on certain causes. The plot has also its own structure like exposition, rising action, climax, falling action and resolution. (T6)

Although discussing the content knowledge of literature was important, linguistic knowledge of the students should also be focused. EFL teachers did not give attention for the students' language learning because they simply forwarded questions designed on the literary texts and proceeded to the next sections. From the observation data, we can deduce that EFL teachers gave little emphasis to linguistic features of literary texts to teach reading skills.

The second point of observation was to examine whether EFL teachers encouraged the students to express their feelings and opinions to make connections between their own personal experiences with those expressed in the texts. Concerning this item, the researcher observed that two EFL teachers asked the students to express their feelings, opinions, attitudes, experiences and thoughts by comparing their own with the text. Even though it was not sufficient, they encouraged the students to express their personal experiences towards the literary text. For instances, T1 and T3 tried to ask the students to express their experiences and feeling towards the literary texts. For example, T1 asked the students "What is your feeling about the poem? What are the feelings? Say something please."

During observation, these two EFL teachers asked the students to express their feelings and experiences on the literary texts. The remaining 4 EFL teachers did not ask the students to express their experience and feeling with respect to the cultures in the literary texts.

Therefore, we can deduce that EFL teachers did not ask the students to express their feelings, attitudes and experiences towards the literary texts. They did not give attention for the students' experiences and feelings. Even there were various questions on the textbook that asked the students to express their feeling, attitudes and experiences about the literary texts, but teachers did not ask them to do those tasks. For instance, let us look at the questions which were related to the students' experiences, attitudes and opinions in the textbook.

- In your opinion, why was Maria a better student than her half-brothers? (p: 46, item: 4)

- What is your opinion of a) Oweka and b) Maria's mother? (p: 46, item: 4)

- Have you ever seen the scorpion? (p. 75)

- Have you ever been stung by the scorpion/snake? (p. 75)

- What would you do if you were stung by the scorpion/snake? (p. 75)

Therefore, EFL teachers should have asked at least these questions to assess their opinions, attitudes and experiences towards the literary texts. However, EFL teachers did not practice such activities that could ignite the students' interest during the reading lessons.

The other point of observation focused on whether EFL teachers explained the social, political, cultural and economic aspects of the literary texts to the students so as to convey the intended meanings of the literary texts. During 
observation sessions, EFL teachers did not mention the political, social, cultural and economic backgrounds of the literary texts. As it is well known the social, cultural, political and economic backgrounds of the literary texts are the key to make the literary texts easy to understand. However, EFL teachers simply did only the activities. Even, there were various questions in the textbook that asked the students to express their culture and the cultures in the literary texts. For example:

- In what ways is the culture depicted in this text: a) similar and b) different from your culture?(p. 45)

- $\quad$ This poem is set in India. How similar is the scene described with the neighbors and the holy man around the mother in her agony similar to what happen in your culture (p. 64).

Like the above questions, EFL teachers could have asked the students to express their cultural view towards the literary texts, but EFL teachers did not explain the socio-economic, political and cultural backgrounds in the texts. Probably, students could understand the literary texts if EFL teachers explained the background information of the literary texts. To sum, the researcher did not observe when teachers gave background information about the texts by their own. They gave little information which was written on the textbook, and they did not provide sufficient information for the students to make the texts easier to understand. For instance, T3 gave the background information of the poem: Two Worlds which is listed on the textbook as "The poem is written by American girl. That girl is disabled. So what do you understand here?" similarly, T1 gave the background information about the texts as "This poem written [sic] by an American girl with a disability." Thus, EFL teachers were limited in giving background information about the literary texts, and they only dictated the information stated in the textbook.

B. Analysis of EFL Teachers' Questionnaire

TABLE-1

RESPONSES RELATED TO THE APPROPRIATENESS OF LITERARY TEXTS TO TEACH READING SKILLS FOR GRADE 11 STUDENTS

\begin{tabular}{|c|c|c|c|c|c|c|c|c|c|c|c|c|c|}
\hline \multirow[b]{2}{*}{ No } & \multirow[b]{2}{*}{ Items } & \multicolumn{2}{|c|}{ SA } & \multicolumn{2}{|l|}{$\mathrm{A}$} & \multicolumn{2}{|c|}{$\mathrm{U}$} & \multicolumn{2}{|l|}{$\mathrm{D}$} & \multicolumn{2}{|c|}{ SD } & \multicolumn{2}{|c|}{ Total } \\
\hline & & $\mathrm{F}$ & $\%$ & $\mathrm{~F}$ & $\%$ & $\mathrm{f}$ & $\%$ & $\mathrm{~F}$ & $\%$ & $\mathrm{~F}$ & $\%$ & f & $\%$ \\
\hline 1 & $\begin{array}{l}\text { Literary texts in the textbook are proportional when } \\
\text { compared to non literary texts to teach reading skills. }\end{array}$ & 1 & 3.33 & 4 & 13.34 & 4 & 13.34 & 17 & 56.66 & 4 & 13.33 & 30 & 100 \\
\hline 2 & $\begin{array}{l}\text { Literary texts in the textbook are suitable for } \\
\text { students' social background. }\end{array}$ & 2 & 6.67 & 8 & 26.67 & 2 & 6.66 & 17 & 56.66 & 1 & 3.34 & 30 & 100 \\
\hline 3 & $\begin{array}{l}\text { The text book provides sufficient stages of reading } \\
\text { activities (pre-reading, while-reading and post- } \\
\text { reading) while using literary texts. }\end{array}$ & 3 & 10 & 12 & 40 & 2 & 6.66 & 9 & 30 & 4 & 13.34 & 30 & 100 \\
\hline 4 & $\begin{array}{l}\text { Literary texts are balanced in different genres of } \\
\text { literature in grade } 11 \text { English textbook. }\end{array}$ & 1 & 3.34 & 7 & 23.33 & 3 & 10 & 15 & 50 & 4 & 13.33 & 30 & 100 \\
\hline
\end{tabular}

When we observe the responses given to item 1 in the above table, $1(3.33 \%)$ of the respondents strongly agreed that literary texts in the textbook are proportional to teach reading skills, and 4 (13.34\%) other respondents agreed. On the contrary, $17(56.66 \%)$ and $4(13.33 \%)$ of the respondents responded 'strongly disagree' and 'disagree' respectively that literary texts in the textbook are proportional when compared to non literary texts to teach reading skills while 4 $(13.34 \%)$ of the respondents remained undecided.

When we examined the responses given to item 2 in the same table, 2( 6.67\%) of the respondents strongly agreed that literary texts in the textbook are suitable for students' social background. $8(26.67 \%)$ of the respondents agreed that literary texts are suitable for grade 11 students where as $17(56.66 \%)$ of the respondents disagreed that literary texts are suitable for the students' social background. 1 (3.34\%) of the respondents also strongly disagreed that they are suitable for grade 11 students social background while 2 (6.66\%) of the respondents remained undecided.

As we can see item 3, $3(10 \%)$ of the respondents strongly agreed that the textbook provides sufficient stages of reading activities (pre-reading, while-reading and post-reading) while using literary texts. The other 12 (40\%) of the respondents also agreed that the textbook contains the stages of reading activities while using literary texts in reading lessons while other $2(6.66 \%)$ respondents left undecided. On the other hand, $9(30 \%)$ and $4(13.34 \%)$ of the respondents responded 'disagree' and 'strongly disagree' respectively. That means, 13 respondents believed that the textbook does not provide pre reading, while reading and post reading activities while using literary texts in reading lessons.

Item 4 shows that $1(3.34 \%)$ respondent strongly agreed that literary texts are balanced in different genres of literature in grade 11 English textbook, and 7 (23.33\%) of the respondents agreed up on this item. On the other hand, 15 $(50 \%)$ respondents disagreed and $4(13.33 \%)$ respondents strongly disagreed that literary texts are balanced in different genres of literature in grade 11 English textbook while $3(10 \%)$ respondents did not decide.

From the above data we can deduce that literary texts are not proportional to non-literary texts; literary texts are not suitable for the students' social background. The textbook does not provide stages of reading activities on literary texts, and literary texts are not balanced in genre. 
TABLE-2

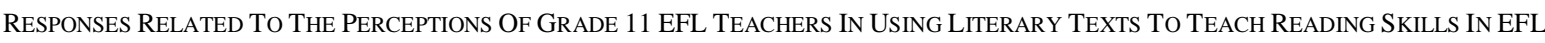
CLASSES

\begin{tabular}{|c|c|c|c|c|c|c|c|c|c|c|c|c|c|}
\hline \multirow[b]{2}{*}{ No } & \multirow[b]{2}{*}{ Items } & \multicolumn{2}{|l|}{ SA } & \multicolumn{2}{|l|}{$\mathrm{A}$} & \multicolumn{2}{|l|}{$\mathrm{U}$} & \multicolumn{2}{|c|}{$\mathrm{D}$} & \multicolumn{2}{|c|}{ SD } & \multicolumn{2}{|c|}{ Total } \\
\hline & & $\mathrm{F}$ & $\%$ & F & $\%$ & $\mathrm{~F}$ & $\%$ & $\mathrm{~F}$ & $\%$ & $\mathrm{~F}$ & $\%$ & $\mathrm{~F}$ & $\%$ \\
\hline 5 & $\begin{array}{l}\text { Students have an opportunity to use literary texts for } \\
\text { literary appreciation. }\end{array}$ & 4 & 13.34 & 9 & 30 & 3 & 10 & 9 & 30 & 5 & 16.66 & 30 & 100 \\
\hline 6 & Literary texts are open for multiple interpretations & 4 & 13.34 & 14 & 46.66 & 7 & 23.33 & 4 & 13.34 & 1 & 3.33 & 30 & 100 \\
\hline 7 & $\begin{array}{l}\text { Help to improve their knowledge of figurative } \\
\text { speeches. }\end{array}$ & 7 & 23.34 & 12 & 40 & 6 & 20 & 5 & 16.66 & - & - & 30 & 100 \\
\hline 8 & $\begin{array}{l}\text { Literary texts help the students to get implicit } \\
\text { meaning through reading beyond the lines. }\end{array}$ & 11 & 36.66 & 15 & 50 & 4 & 13.34 & - & - & - & - & 30 & 100 \\
\hline 9 & $\begin{array}{l}\text { I enjoy teaching reading skills by using literary texts } \\
\text { like poems, short stories and novels. }\end{array}$ & 7 & 23.34 & 15 & 50 & 2 & 6.66 & 5 & 16.66 & 1 & 3.34 & 30 & 100 \\
\hline 10 & $\begin{array}{l}\text { It is good opportunity for students to link their } \\
\text { experiences with the experiences in the literary texts. }\end{array}$ & 11 & 36.66 & 15 & 50 & 3 & 10 & 1 & 3.34 & - & - & 30 & 100 \\
\hline
\end{tabular}

(Key: SA=Strongly Agree A=Agree U=Undecided D=Disagree SD=Strongly Disagree $f=$ frequency)

According to item 5 in the table above, 13 (43.34\%) of the respondents (4 strongly agreed and 9 agreed) supported the item that students had an opportunity to use literary texts for literary appreciation. On the other hand, 14 (46.66\%) of the respondents ( 5 strongly disagreed and 9 disagreed) disagreed that students had an opportunity to use literary texts for literary appreciation. $3(10 \%)$ respondents left undecided. Therefore, $13(43.34 \%)$ of the respondents have the perception that students have the opportunity to use literary texts for literary appreciation.

Item 6 in the same table shows that $4(13.34 \%)$ of the respondents strongly agreed and $14(46.66 \%)$ of the respondents agreed that literary texts are open for students for multiple interpretations while learning reading skills while $7(23.34 \%)$ of them remained undecided. On the contrary, 4 (13.34\%) respondents disagreed and 1 (3.34\%) respondent strongly disagreed that literary texts are open for students for multiple interpretations while learning reading skills. From this empirical data, we can understand that $18(60 \%)$ respondents agreed that literary texts are open for multiple interpretations to learn reading.

Based on item 7, 7 (23.34\%) respondents strongly agreed and $12(40 \%)$ of the respondents agreed that students improve their knowledge of figurative speeches by using literary texts in reading lessons. 5 (16.66\%) of the respondents disagreed that students improve their knowledge of figurative speeches by using literary texts in reading lessons while the other $6(20 \%)$ of them remained undecided. So, item 7 tells us that students can improve their knowledge of figurative languages through literary texts.

According to item 8 in the above table, 11 (36.66\%) of the respondents strongly agreed and $15(50 \%)$ of the respondents agreed that using literary texts help the students to get implicit meaning through reading beyond the lines. Whereas 4 (13.34\%) of them left undecided, and none of the respondents disagreed on this item. Therefore, from this item we can deduce that using literary texts help the students to get implicit meaning through reading beyond the lines.

As item 9 deals with, 7 (23.34\%) of the respondents strongly agreed and $15(50 \%)$ of them agreed that they enjoyed teaching reading skills by using literary texts like short stories, poems and novels where as $6(20 \%)$ of the respondents disagreed that they enjoyed teaching reading skills by using literary texts. The other $2(6.66 \%)$ respondents were unable to decide. Again, in this item we can deduce that they enjoyed teaching reading skills through literary texts.

As we can see from item 10, $11(36.66 \%)$ of the respondents strongly agreed and $15(50 \%)$ of the respondents agreed that it is good opportunity for students to link their experiences and the experiences in the literary texts. The other 3 $(10 \%)$ of the respondents were unable to decide, and $13.34 \%)$ respondent disagreed that it is good opportunity for students to link their experiences and the experiences in the literary texts. From this item, it can be concluded that literary texts create good opportunities for students to relate the experiences of the texts with their own experiences.

To sum, from the above items $(5,6,7,8,9$ and 10) we can deduce that literary texts had opportunities for students for literary appreciation; they were open for multiple interpretation; they improved students' knowledge of figurative speeches; they enabled the students to get implicit meaning from the reading text; literary texts are enjoyable for teaching reading skills, and they created good opportunity to link the experiences of texts with the students' experiences. As a result, EFL teachers had positive attitudes towards using literary texts in reading lessons. They perceived that literary texts were important to facilitate language learning and teaching, and literary texts enabled the students to get implied meanings from the texts by providing certain clues. 
TABLE-3

RESPONSES RELATED TO EFL TEACHERS' IMPLEMENTATIONS OF LITERARY TEXTS TO TEACH READING SKILLS IN EFL CLASSES.

\begin{tabular}{|c|c|c|c|c|c|c|c|c|c|c|c|c|c|}
\hline \multirow[b]{2}{*}{ No } & \multirow[b]{2}{*}{ Items } & \multicolumn{2}{|c|}{ SA } & \multicolumn{2}{|l|}{$\mathrm{A}$} & \multicolumn{2}{|l|}{$\mathrm{U}$} & \multicolumn{2}{|l|}{$\mathrm{D}$} & \multicolumn{2}{|c|}{ SD } & \multicolumn{2}{|c|}{ Total } \\
\hline & & $\mathrm{F}$ & $\%$ & $\mathrm{~F}$ & $\%$ & $\mathrm{~F}$ & $\%$ & $\mathrm{~F}$ & $\%$ & $\mathrm{~F}$ & $\%$ & $\mathrm{f}$ & $\%$ \\
\hline 11 & $\begin{array}{l}\text { I involve the students in literary texts emotionally to } \\
\text { learn target language by focusing on personal } \\
\text { experiences. }\end{array}$ & 5 & 16.66 & 22 & 73.34 & 2 & 6.66 & 1 & 3.34 & - & - & 30 & 100 \\
\hline 12 & $\begin{array}{l}\text { I direct the students to analyze literary texts to their } \\
\text { real life situations. }\end{array}$ & 7 & 23.34 & 17 & 56.66 & 2 & 6.66 & 2 & 6.67 & 2 & 6.67 & 30 & 100 \\
\hline 13 & $\begin{array}{l}\text { I encourage students to associate the themes of the } \\
\text { literary texts with their personal experiences. }\end{array}$ & 9 & 30 & 17 & 56.66 & 3 & 10 & 1 & 3.34 & - & - & 30 & 100 \\
\hline 14 & $\begin{array}{l}\text { I focus on the themes of literary texts while using } \\
\text { literary texts. }\end{array}$ & 3 & 10 & 19 & 63.34 & 3 & 10 & 5 & 16.66 & - & - & 30 & 100 \\
\hline 15 & $\begin{array}{l}\text { I link the literary texts and the biography of the author } \\
\text { with the literary elements. }\end{array}$ & 2 & 6.66 & 18 & 60 & 5 & 16.67 & 5 & 16.67 & - & - & 30 & 100 \\
\hline 16 & $\begin{array}{l}\text { I explain the background information about the literary } \\
\text { texts for the students to convey the intended meanings. }\end{array}$ & 4 & 13.34 & 10 & 33.33 & 2 & 6.66 & 13 & 43.33 & 1 & 3.34 & 30 & 100 \\
\hline
\end{tabular}

(Key: SA=Strongly Agree A=Agree U=Undecided $D=$ Disagree $S D=$ Strongly Disagree $f=$ frequency)

As we understand from the responses given to item 11 in the table above, $5(16.66 \%)$ of the respondents strongly agreed and $22(73.34 \%)$ of the respondents agreed that they involved the students in literary texts emotionally to learn target language by focusing on personal experiences. On the other hand, $1(3.34 \%)$ respondent disagreed and the other remaining $2(6.66 \%)$ of the respondents were unable to decide. Item 12 tells us that $24(80 \%)$ respondents (7 strongly agreed and 17 agreed) agreed that they directed the students to analyze literary texts to their real life situations to make meaningful interpretations. The other $4(13.34 \%)$ of the respondents responded that they did not direct the students to analyze literary texts to their real life situations while the remaining $2(6.66 \%)$ respondents left undecided.

Based on the information from item 13,9 (30\%) of the respondents strongly agreed and $17(56.66 \%)$ of the respondents agreed that they encouraged students to associate the themes of the literary texts with their personal life experiences. The other $3(10 \%)$ of the respondents were unable to decide and $1(3.34 \%)$ respondent disagreed with this idea. In item 14, $3(10 \%)$ of the respondents strongly agreed and $19(63.34 \%)$ of the respondents agreed that they focused on the themes of literary texts while using literary texts. The other $5(16.66 \%)$ of the respondents responded that they did not focus on the themes of literary texts, and the remaining $3(10 \%)$ respondents were unable to decide.

As we can see from item 15 in the same table, $20(66.66 \%)$ of the respondents $(6.66 \%$ strongly agreed and $60 \%$ agreed) agreed that they linked the literary text and the biography of the author (intentions, situations and the setting in an author's life) with the literary elements. On the other hand, 5 (16.66\%) of the respondents disagreed that they linked the biography of the author, and the remaining 5 (16.66\%) respondents left undecided. Item 16 shows that 4 (13.34\%) of the respondents agreed strongly that they explained the background information about the literary texts for the students to convey the intended meanings. $10(33.34 \%)$ of the respondents also agreed with this idea where as 14 $(46.66 \%)$ of the respondents disagreed that they explained the background information about the literary texts for the students to convey the intended meanings. 2 (6.67\%) respondents were unable to decide.

From the above data, we understand that EFL teachers involved students in literary texts emotionally by focusing on personal experiences; they directed the students to analyze literary texts to their real life situations to make meaningful interpretations; they encouraged students to associate the themes of the literary texts with their personal experiences; they focused on the themes of literary texts while using literary texts; they linked the literary text and the biography of the author, and they did not explain the background information about the literary texts for the students to convey the intended meanings. Although the background information like political, social, cultural and economic situations of the texts are important for the students to understand the texts, EFL teachers did not explain background information about the literary texts.

\section{Analysis of EFL Teachers' Interview}

The first item was asked to determine the appropriateness of literary texts for the students' age, interest, cultural background, linguistic background, linguistic proficiency, literacy background and social background. Each of the interviewees responded as follow:

The first teacher (T1) claimed "Most of the time, literary texts do not fit students' ability, students' capacity and cultures. Students are not involved in a good manner. Most of the time literary texts are beyond their capacities." The second teacher (T2) also argued "The literary texts are not appropriate, they reflect the external world. They cannot appropriately touch the students' culture, and they are not designed based on their culture. As a result, Students cannot understand the meaning." Similarly, the third teacher (T3) said "Literary texts are not suitable for students' background level and linguistic proficiency because students do not have background information about the texts. They are far from the students' culture."

Moreover, the fourth teacher (T4) also pointed out "Literary texts are especially appropriate for their age, but they are new for their cultural background. Especially, the languages that are used in literary texts are too difficult for them to understand even for the teacher." Besides, the fifth teacher (T5) asserted "The literary texts are not well designed and suitable for the students. Literary texts do not fit in terms of their age, their interest, cultural background, linguistic 
background and their linguistic proficiency. The vocabularies in the literary texts are not plain for the students' level, so they are unable to understand the literary texts." The sixth teacher (T6) stated "The literary texts in the text book are not prepared by considering the students' multi cultural background; they are not capable of understanding the language what is written in the literary texts, they are not interesting; they do not match with the students' cultural background and linguistic background."

From the responses above, we can conclude that literary texts designed on grade 11 English textbook are not suitable for the students' age, interest, cultural background, linguistic background, linguistic proficiency, literacy background and social background. They are not selected by considering the students language ability, interest, culture and literacy background.

The second item dealt with whether EFL teachers gave background information about the literary texts so as to make multiple interpretations of the texts or not. In this item, the biography of the author, historical, political, cultural and social backgrounds of the literary texts were asked. Let us look at the responses of interviewees here under.

$\mathrm{T} 1$ responded "I do not give students any information about the text because students are not reading when I give some necessary information before reading." Similarly, T2 said "I did not give sufficient background information for the students, and I sometimes told them about the characters and the plot structures of the literary texts." T3 replied "I tried in such a way, but the background of the author is far from the students' background. So, I tried but no longer at all. I tried to tell them the cultural and political information but that is not much."

In addition, T4 replied "If there are some hints in a given literary text, especially during the pre reading activities, I discus some points with my students. Unless and otherwise, I did not do such activities in my own. Even, I skip the literary texts when I am in hurry." T5 also said "I did not tell the authors' information since I did not know most authors. I explained the characters and the plot structures of the texts, but I did not do much about the background information about the literary texts." On the other hand, T6 replied "I give background information about the literary texts."

From the above discussion, most of the interviewees described that they did not give sufficient background information about the literary texts to make multiple interpretations of the texts. However, two EFL teachers said that they tried to give such background information about the texts although it was not much enough. Hence, we can conclude that EFL teachers had limitations on giving background information about the literary texts, and they were not willing to give extra information for the students.

The third item described whether EFL teachers gave opportunities for the students to express their own personal feelings, emotions, opinions and experiences on the literary texts. The responses of each interviewee are summarized as follow:

T1 replied "Sorry, most of the time I do not give because the texts are very long and huge, and the time is not enough to do the activities. So, it is impossible to give chances for the students to express their own feelings." On the other hand, T2 said "I try to give a chance to express what they feel." T3 also said "At the very beginning, I have already given opportunity and I share my experiences."

Furthermore, T4 described his practice as "I simply do the exercises which are listed in the literary texts. Unless and otherwise, I did not ask them to say something concerning on the points." On the other hand, T5 responded "Most of the time I try to give the student to express their feelings, their emotions and their opinions without any frustration." Like T5 did T6 responded "I just make the students read the text and I forced them to forward their feeling. Even I tried to express my personal opinion and experience in relation to the text."

From the above data, majority of interviewees said that they did not give opportunity for the students to express their feelings, opinions and experiences about the literary texts. On the other hand, minority of respondents (T5 and T6) said that they forced the students to share their experiences after they had read the literary texts. Therefore, it can be deduced that most EFL teachers did not give opportunities for the students to express their own personal feelings, emotions, opinions and experiences on the literary texts.

The last item focused on the challenges that faced while using literary texts to teach reading in EFL classes. EFL teachers mentioned their challenges that faced while using literary texts in EFL classes as follow. T1 replied "The first challenge we experience that we depend on only grammatically parts and we ignore these literary texts. The next one is the preparation of literary texts by themselves; I think they are difficult for students' ability and background knowledge." T2 also pointed out "Literary texts are very broad for the students. The students cannot understand them. It is difficult to get the meanings from the literary texts to relate their lives." Besides, T3 stated "The students have no interest on literary texts. They are not [sic] background information about literary texts. The task by itself is difficult. There is no Amharic and English fiction in our school."

Furthermore, T4 stated "The first barrier is the students' lack of interest. The second difficulty is the language usage in the literary text especially in poems; the language usage is difficult for the students, even for the teacher. And the other difficulties are the culture where the literary text is taken from." Similarly, T5 replied "One challenge is that the students are not familiar with literary texts; the second is the students are not interested; another problem is also cultural unfamiliarity of the texts." T6 also stated "What challenged them are the inability to understand literary texts easily and language difficulty. Basically the language is difficult that enables to understand the poem as easily as possible." 
Based on the above data, the challenges of using literary texts to teach reading skills were summarized as follow. Students were unable to understand the literary texts; students have no interest to read literary texts; they do not have background information about literary texts; the tasks are difficult, and students are not familiar with the cultures of texts. Besides, there are no literary texts in the schools, and teachers ignore literary texts. Furthermore, the languages in the literary texts are difficult to understand; literary texts are too long for the students; the linguistic expressions are difficult, and literary texts are beyond the students' level of intellectual maturity.

\section{Analysis of Literary Texts and Their Activities}

Poem: Night of the Scorpion (p.74)

The poem is written by one of Indian famous poet: Ezekiel Nissim. It describes what happened when the writer's mother was stung by the scorpion. It is 48 lines long, and relatively the poem is too long to understand the text within a given time. Since it is very long, it is not attractive and enjoyable for grade 11 students. One of the characteristic features of a poem is that a few selected and powerful words should be used. On the contrary, this poem contains many words which are not selected properly. As a result, students are not interested by the poem.

The culture which is depicted in the poem is not related to the students, and it is not practiced by the students. Due to this reason, the culture is unfamiliar for the students. Rarely, such situations can occur in dessert areas of Ethiopia in which persons are stung by scorpion and snake, but in most areas, there is no scorpion. The social structure of the society in the poem is nearly similar to the students' environment. For instance, when in challenge, the community gathers together to help the persons who are in need. Likewise, when the mother was stung by the scorpion, the villagers gathered together and perform their cultural traditions. For example, "The peasants came like swarms of flies and buzzed the name of God a hundred times to paralyze the Evil one (line-8).",

Besides, the expressions are complex for grade 11 students to understand easily because there are difficult words in the poem. As a result, students are not familiar with such kind of poem even in their environments. Since they are new for such text, the theme is also irrelevant for the students, and it is not related to the students' real life experiences.

However, this poem can improve the students' language awareness, and it creates positive language learning environment like grammar and vocabulary. The poem can also expose the students to unexpected, complex and fresh language structures, and it enables the students to think critically. Since the source is available in the textbook, students can get the full version to read the rest parts of the poem in and out of the school.

The poem does not have pre reading activities that enable the students to create interest. There is only one single instruction before reading the poem: "Read the poem and then do the exercises below". This instruction does not create interest for the students; rather, it commands what they are going to do next. Many pre reading activities should have been designed concerning to this poem. For example:

a) Have you ever seen the scorpion?

b) Have you ever stung by the scorpion/snake?

c) What would you do if you are stung by the scorpion/snake?

d) What treatments should be given for the one who is stung by the scorpion?

However, the poem contains while reading and post reading activities. Particularly, the poem contains many post reading tasks than while reading activities. Some instructions are not clear not only for the students but also for the teachers. For example: "Do you know why it would have been very serious if one of the children had been bitten by the scorpion rather than their mother (item 4a)?" Moreover, there are too many questions in one instruction. Instead of assessing different tasks by integrating the language skills, numerous items are designed in an instruction. For example, there are 10 items (A-J) in the first instruction, and there are also 11 items (A-K) in the third instruction. Too many similar items can make the students bored with the questions. However, the activities are integrated each other. Through reading the poem, speaking and vocabulary activities are included. For example:

"Find words meaning the following in parts of the poem indicated.

a) Like a devil, cruel and wicked (line 1-9)

b) To make something unable to move (line 01-19) and so on."

The activities assess the students' cultural background, and attempt is made to relate the culture of the poem with the students' culture. For example: "This poem is set in India. How similar is the scene described with the neighbors and the holy man around the mother in her agony similar to what happens in your culture (item 4d). The activities also relate the poem with their feelings, attitudes, thoughts and personal experiences. For instance, "Have you or someone close to you ever been bitten by a scorpion, or dangerous insect, spider or snake? Describe what happened (item 4e). The activities also enable the students to evaluate the intentions of the author, and they are left for the students for multiple interpretations.

Story: The Tale of a Tap (p. 199)

This text is mainly designed to teach reading skills. The text is not attractive so as to create the students' interest to read the whole text on the textbook. The text does not consider the students' language proficiency as it is full of long 
sentences. The sentences are difficult not only for the students but also for the teachers. Reading two pages of unfamiliar text in a period is not an easy task for the students, and it is left tiresome to understand the text since the text is too long to read.

The text does not also consider the students' cultural and social background. The text is extracted from 'Drum Magazine' in West Africa. So, how could Ethiopian students with limited language proficiency understand the central meaning of the text? Actually, scarcity of water supply is the issue for the people, but the way of expressions in this tale is different from that of Ethiopians. Since the students do not understand it very well, students remain passive throughout the lesson. Although exposing the students with natural uses of language is a good opportunity, it is difficult to comprehend the text by their own. The students are not also given chances to express their feelings, attitudes and personal experiences. They are simply ordered to read the text and do the comprehension questions.

Unlike the text, the activities are clear to understand for the students. The items are simple enough to answer the questions, and they are comprehensible for the students' level of intellectual maturity. The activities assess the students' cultural background and background knowledge of the text. They are asked to reflect their own feelings, experiences and thoughts. For example:

- What would you do if you had been in the writer's situation? (item 1)

- Do you find the story amusing? Give reasons for your answer. (item 1)

The instructions are also clear what to do, but it lacks pre reading activities. Students are directly required to read the text without igniting their interest about the topic. Students are not exposed to the pre reading stage and they are told to read the text without any background information.

\section{Poems: Two Worlds, Palm Leaves of Childhood and Why the Old Woman Limps}

These three poems on pages 240, 243 and 252 respectively are designed to teach reading skills. These poems are designed in the foreign contexts, and students are not familiar for these texts, but the issues that they raise are familiar for the students. They deal with disability, childhood memory and burdens of women respectively. When compared to the former poems in the textbook, these poems are interesting and enjoyable for the students. They are short enough to transmit messages, and they give sense when they are read. The cultural, political and social problems raised in the poems are familiar for the students. Students are also familiar for such types of poems in their locality, and they are impressed by these poems. The texts fit the intellectual maturity of the students to understand by their own because the texts enrich the students' feelings, attitudes, opinions, thoughts and experiences.

The students can develop their language by reading these poems. Students are also exposed to the new, fresh and unexpected uses of language, and they can benefit from the poem very much. They also expand the students' language learning and critical thinking ability. Besides, these three poems are short enough to create images on the students' minds. For instance, 'Two worlds' is written by an American girl with disability. She describes her challenges by saying 'Two Worlds'. She also states her sorrow for being disabled. For example:

Tears flow...

Unknowingly both push away,

Rejected, made to feel

Unbelonging... (p. 240)

On the contrary, on the third poem (Why the old woman limps), there is a culture of milking goats and selling their milk. In Ethiopian context, milking goats is not familiar trends except some of the desert areas. For example,

"Each day she milks the goat, sells the milk to buy soap,

Feeds and washes the children, and tethers the goat."

Conversely, the burdens of grandmother are common for the students. The grandmother based on the students' culture has various tasks to do for her grand children. She has to look after them, feed them and wash them while her sons and daughters are outside the house.

The activities are designed in clear and simple ways. Students can easily understand the activities, and tasks are comprehensible for the students to answer comprehension and discussion questions. The activities assess the students' cultural background, and students are requested to express their feelings, opinions and experiences. For example,

- Discuss your feelings about the poem (p. 240)

- To what extent are there people in Ethiopia who live similar lives to this old woman?

- What is your opinion of the poem? (p. 253)

Moreover, the instructions are clear for the students to answer. As a result, students are free to express their feelings, and the poems enable the students to develop intellectual, motor and social skills. On the other hand, the poems do not have pre reading activities while there are few while reading tasks. Most activities are listed under the post reading stages. The activities are highly integrated with language skills.

From the data, literary texts and their activities are not suitable for the students, and they are not designed based on the students' interest and needs. They are designed without considering the students' culture, experiences and feelings. In addition, the activities are also designed without involving the students' needs, and they lack pre reading and while reading tasks.

\section{FINDINGS AND RECOMMENDATIONS}




\section{A. Findings}

Based on the analysis and discussions of the study, the following main conclusions were made.

$>$ Literary texts designed in grade 11 English textbook are not suitable for the students' age, interest, cultural background, social background, linguistic proficiency and literacy background, and they are not selected by considering the students' needs.

$>$ The reading tasks on literary texts are not designed for the improvements of the students' reading skills. They have no pre-reading activities, some while-reading activities and plenty of post-reading activities which are not well designed; some activities lack clear instructions, and some of them are not comprehensible for grade 11 students.

$>$ Grade 11 EFL teachers had positive perception towards using literary texts to teach reading skills. They perceived that literary texts are open for multiple interpretations; they improve the students' knowledge of figurative speeches; they enable the students to get implicit meaning from the reading text, and they are enjoyable for teaching reading skills.

$>$ However, the actual practices of using literary texts to teach reading skills were unsatisfactory. Although EFL teachers perceived that literary texts are important to facilitate the reading classes, they did not practice literary texts meaningfully. The perceptions of EFL teachers towards using literary texts did not match with their actual practices. As a result, EFL teachers sometimes skipped the literary texts by ordering the students to read by their own.

$>$ Difficulty level of the literary texts and their tasks, unfamiliarity of the cultures from texts, idiomatic expressions from the texts, lengthy of texts, vague instructions of tasks, lack of interest, limited reading experiences, lack of background information about the texts, unable to make texts interesting and unable to modify literary texts were the major difficulties that faced students and EFL teachers while using literary texts in reading lessons. These challenges highly hinder the proper use of literary texts to teach reading in EFL classes.

\section{B. Recommendations}

Based on the conclusions made above, the following recommendations were suggested.

$>$ Textbook writers and syllabus designers should revise grade 11 English textbook to have literary texts that consider the students' age, interest, cultural background, social background, linguistic proficiency and literacy background.

$>$ Textbook writers, syllabus designer and EFL teachers need to supervise the literary text based activities to have well designed pre-reading, while-reading and post-reading tasks with clear instructions so as to make the reading through literary texts comprehensible for the students.

$>$ Instead of skipping, EFL teachers should practice every literary text and their tasks on the textbook by providing students with cultural, political, social, economic and literary background information of the literary texts to make the reading lessons understandable for the students.

$>$ EFL teachers have to give opportunities for the students to express their feelings, opinions, personal experiences and real life situations on literary texts to make sense of texts in reading lessons.

$>$ Students should engage themselves in reading different literary texts and reading activities to improve their reading performances, to increase their vocabulary and to familiarize the texts for themselves.

\section{REFERENCES}

[1] Abdollah, K. (2012). Use of literature in teaching English. Procedia - Social and behavioral sciences (46) 554 - 559. Islamic Azad University, Iran.

[2] Alene Ketema. (2012). Investigation of EFL teachers' and students' views towards using literary text in EFL classrooms. (Unpublished MA Thesis). Haramaya: Haramaya University.

[3] Brown H. D. (2001). Teaching by principles: An interactive approach to language pedagogy. New York: White Plains.

[4] Carter, R., \& Long, M.N. (1986). Teaching literature. United States of America: Longman.

[5] Carter, R., \& Long, M.N. (1991). Teaching literature. New York: Longman.

[6] Creswell, J. W. (2012). Educational research: Planning, conducting, and evaluating quantitative and qualitative research. $\left(4^{\text {th }}\right.$ ed.). Boston: Pearson Education, Inc.

[7] Elena, S. T. (2016). Literature in ELT setting: Students' attitudes and preferences towards literary texts. International conference on teaching and learning English as an additional language. 14/17. 160-169. Antalya, Turkey.

[8] Federal Democratic Republic of Ethiopia, Ministry of Education. (2003 E.C.). English for Ethiopia: Student text book for grade 11. England: Pearson Educational Limited.

[9] Freeman, L. D. (1986). Techniques and principles in language teaching. (2 ${ }^{\text {nd }}$ ed.). England: Oxford University Press.

[10] Hana Fikru (2016). The role of short story in developing reading comprehension skill. (Unpublished MA Thesis). Addis Ababa: Addis Ababa University.

[11] Ibrahim, M. (2014). Using literature in EFL classes: Assessing the suitability of literary texts to secondary school students. European Journal of English Language and Literature Studies Vol.2, No.4, pp. 9-21.

[12] Lazar, G. (1993). Literature and language teaching. Cambridge: Cambridge University Press.

[13] Lazar, G. (1999). A window on literature. Cambridge: Cambridge University Press. 
[14] McKay, S. (1982). Literature in the ESL classroom. TESOL Quarterly Vol. 16, No. 4, pp.529-536.

[15] Nuttall, C. (1982). Teaching reading skills in a foreign language. London: Heinmann Educational Ltd.

[16] Ozkan, A. \& Nejat, T. (2014). Use of literature in reading comprehension classes by ELT teachers. The international journal of social sciences. Vol. 25. No. 1. ISSN 2305-4557, pp 66-72.

[17] Phillips, S. (1993). Young learners. Oxford: Oxford University Press.

[18] Povey, J. (1972). Literature in TESL programs: The language and the culture. In H. Allen \& R. Campbell (eds.) Teaching English as a second language. New York: McGraw Hill.

[19] Ramnath, R. (2016). Literature in language teaching: What, why and how? Proceedings of international conference on science, technology, humanities and business management. 104. Bangkok, Thailand

[20] Stern, H. H. (1983). Fundamental concepts of language teaching. Oxford: OUP.

[21] Yenealem Tesfaye (2014). Assessing teachers' and students' views regarding the role of literary texts in enhancing language use. (Unpublished MA thesis). Haramaya: Haramaya University.

Netsanet Haimanot has an M.A. in Teaching English as a Foreign Language. He has taught English for over fifteen years in high schools and universities. He is now an instructor in Injibara University.

Sualih Mussa has a Ph.D. in Teaching English as a Foreign Language. He has taught English for over twenty years in high schools and universities. He is now an instructor in Debre Markos University. 